\title{
Inspectional Regulations in the Latest Period of Ottoman Time
}

\author{
Mehmet Emin Usta \\ Faculty of Education, University of Harran, Turkey
}

Copyright $\bigcirc 2018$ by authors, all rights reserved. Authors agree that this article remains permanently open access under the terms of the Creative Commons Attribution License 4.0 International License

\begin{abstract}
One of the most controversial issues about education in Turkey and around the world is inspection of education. Some countries conduct educational auditing through inspectors. Some countries, such as Finland, consider that there is no need for a mechanism such as an inspectorate, but instead considering public scrutiny. Inspectional Regulations in the Latest Period of Ottoman Time $^{1}$ aims to shed light on the history of educational inspection in Turkey and to expose the history of the inspectors' duties and authorities and audit areas. In this scope, documents older than about a century were found and translated from the Ottoman Language. Document analysis method was used in this study. When the documents were evaluated as a whole, it was stated that the religious dimension of education was no longer inspected by the Republican regime founded in 1923 and secularization, but especially that bureaucratic control continues in different forms; the quality of education is still a matter discussed in Turkey; it is understood that the inspectors' school-related duties are still continuing and this situation continues to be a problem that is gradually diminishing in Turkey.
\end{abstract}

Keywords Ottoman Empire, Inspection of Education, Duties of Inspectors, History of Education

\section{Introduction}

Contemporary control today is to determine the extent to which the services rendered comply with the law and the prescribed rules. Educational inspection is perceived as a way of informing the administrators and teachers at every level who work in the field of management and education rather than evaluating teachers and administrators in terms of discipline, providing effective guidance services to them

\footnotetext{
${ }^{1}$ A brief summary of this work was presented in a conference at the Global Conference on Education and Research in Manatee Sarasota (USA) on 22-25 May 2017.
}

and fulfilling contemporary guidance function [7].

Inspection history in Turkish context can simply be divided into two as: Ottoman Period and Republic Period. During Ottoman time, western style modern schools were mostly owned and managed by religious communities. There was not a proper structure or institution to inspect those schools notwithstanding Sibyan (Primary) and Rüştiye schools (secondary) were audited by specific inspectors named Muin(s). After 1862, though not in expected levels, in line with the increase in school numbers, the terms "inspection" and "inspector" started to be seen in official documents. Staffs with auditing and inspection responsibilities were called as muin (controller) or muhakkik (investigator) [10]. With this study, it is aimed to present the attempts to improve education by using inspection as a development triggering tool, in the latest period of Ottoman State. Both staff roles are also named inspectors as an umbrella term. Inspectors carried out their duties due to the principles -named talimatname- dictated by Ottoman ministry of education of that time.

\section{Educational Inspection during Ottoman Time}

The inspection system is a system designed to enable the organization to realize its objectives by inspection tools. It was understood that the need for the inspection system in the Turkish Education System was the most effective in the Ottoman Empire renovation activities and started to be felt in the period of Tanzimat Period in 1839. The main backbone of the inspection system was established in 1839 and in the following periods it was tried to be adapted to the requirements of the relevant legal regulations [3]. According to Taymaz [4], it is not clear exactly when the educational inspections started in the Ottoman Empire. However, there are many documents with educational inspections. Some of these are [4], [2], [10], [11], [14], [13]:

- 1838: Inspecting the schools of the officers responsible for the elimination of deficiencies and remedying these deficiencies. 
- 1846: Establishment of municipalities responsible for the inspection of primary school (Mekatib-i Sibyaniye) and junior high school (Mekatib-i Rushdiye).

- 1862: Inspector test for those responsible for primary school (Mekatib-i Sibyaniye) and secondary school (Mekatib-i Rushdiye) inspections for the first time.

- 1875: For the first time, it is stated that the inspection record books should be kept in the schools to be inspected and that this record book will be shown to the inspectors when requested.

- 1876: Publication of an instructions list on inspection by the Assembly.

- 1910/1911: Publication of the Directive on the Duties of Primary School Inspectors.

- 1911: According to the provisions of the Central Organization Regulation of the Ministry of Education, central services are divided into administration and inspection. In addition, the selection of inspectors from middle and high school teachers is the basis.

- 1912: It is clearly stated that the duties of the inspectors are over the educational work and the investigation.

- 1913: It is stated that the primary school inspections should be done by the primary education inspectors and that the primary education inspectors have three duties as inspections, investigations and enlightening the public.

- 1914: Publication of the "Instructions on the Duties of the Training Inspectors" on which the principles to be considered by educational inspectors in the inspection of the institution shall be issued.

As can be understood from the chronology above, during the Ottoman Empire, the inspection system developed from simple to complex, from amateur practices to professionalism. Educational inspection has played an increasingly strong role in the overall education system.

In addition, it is possible to summarize the development of educational inspection in the Republic of Turkey, after the Ottoman Empire. In 1923, the instruction letter of the Ministry of Education Inspectorate was published. In 1926, the supervisors of the deputies, who were divided into central and regional inspectors, were reunited in 1931. The formation and duties of the 1933 Inspection Board were rearranged (http://tkb.meb.gov.tr/).

Educational inspectors were assigned in various ways especially after 1950. Güngör (1960) stated that there were thirteen types of inspectors and they were responsible for the inspection of courses that they teach originally such as literature, arts, foreigner language, etc. The inspectors involved are candidates doing two and four months' courses, auditors, pedagogically educated inspectors, and inspectors educated in other countries (Güngör, 1960; cited by Güçlü, 2011). Later, though the amendment of the foundation law of the Ministry of National Education was made at various dates, the structure of the inspection in general was maintained. In 1992, according to the Law on the Organization and Duties of the Ministry of National Education, the Inspection Board took place as the "supervisory unit" within the central organization of the Ministry of National Education. In 1993, the Ministry of National Education Inspection Board Regulation and Regulation entered into force. In 2011, the Board of Inspection of the Ministry of National Education was abolished and instead, the Directorate of Guidance and Supervision was established. In 2014, the titles of National Education Supervision and Provincial Education Supervision were merged with the titles of Education Inspector and National Education Supervisors were appointed to the Presidency of Education Inspectors established within the Provincial National Education Directorates. In 2016, the Board of Inspectors Board of Education was removed and the Board of Inspectors was established at the Ministry of National Education (http://tkb.meb.gov.tr/).

\section{Purpose of the Study}

One of the most controversial issues about education in Turkey and around the world is inspection of education. Some countries conduct educational inspection through inspectors. Some countries, such as Finland, consider that there is no need for a mechanism such as an inspectorate, but instead consider public scrutiny. Again, one of the most controversial discussions on the education system in Turkey is the question of how the inspection system should be, who controls it, what the competencies of the inspectors should be, and what the inspectors should control. According to the provisions of the Decree on the Organization and Duties of the Ministry of National Education, dated 02/12/2016 dated 02/12/2016 and according to the provisions of the Decree of the Ministry of National Education, the duties of the Education Inspectors are determined as guidance, in-service training, inspection, evaluation, investigation and researching. There are currently ministry education inspectors affiliated to the Board of Inspectors in Turkey and education inspectors serving in the provinces [9]. The aim of this study was to reveal some information about the duties and authorities of the education inspectors during the Ottoman Empire period, based on the documents and shed light on the history of the inspectors. In this context, three documents dated 1895, 1906 and 1911 taken from the Ottoman Archives of the Prime Ministry were transcribed and converted from Arabic alphabet to Latin alphabet ${ }^{2}$. The reason why the

\footnotetext{
2 Aforementioned guideline was obtained and translated as part of a research Project (research ID: 1845) entitled "Education Inspection in Ottoman Empire from Declaration Of The Constitution (1876) to Republican era (1923)" that was conducted by Prof. Dr. Fatma ÖZMEN,
} 
documents are Arabic is that the Arabic alphabet was used in all the correspondences throughout Ottoman history. After the collapse of the Ottoman Empire, in 1928, the Arabic alphabet was abandoned and the Latin alphabet was used in all the letters [1]. Following this process, the duties and authorities of the educational inspectors in the document were evaluated by the author. In addition, documents converted to Latin alphabet have been added to the study.

This research aimed to reveal what was inspected by the duties and authorities of the education inspectors during the Ottoman Empire and the students in the education system. For this purpose, the answers to the following questions were searched:

1. Was any educational inspection carried out during the Ottoman Empire period? How were they done?

2. What were the signs and behaviors that were considered important in the education system?

\section{Methodology}

Documentary analysis method was used for his study. This method aims to display historical and current realities as they are. Documentary analysis is about extrapolating and finding relations between written things by using historical and recent documents. Historical data are accepted as this method's study area. Beside historical documents, archeological heritages are also conceived as sources to analyze [6]. In this regard, Archives of Istanbul University Library and Prime Ministry Archives were looked over for possible official documents about inspection issues related to the latest Ottoman period. Found examples were transcribed into modern Turkish letters to enhance understanding. Finally, findings are presented and then compared to the contemporary application in Turkey.

The use of the documentary screening model in the research relates to the nature of the historical research, because evidence can be put in place for historical investigations to be made. The documents obtained are evidence. These documents have been simplified in language terms. In this research, the following stages were followed in accordance with the documentary screening model:

1. A literature study on the subject has been made and the information given in the introduction section.

2. Historical documents contained documents or documents that shed light on the subject.

3. The relevant document has been translated from Ottoman to Latin alphabet.

Prof. Dr. Erdal Açıkses, Asst. Prof. Dr. Mehmet Emin USTA, and Asst. Prof. Dr. Sitk1 ULUERLER and also funded by Firat University Scientific Research Projects Coordination Unit.
4. In the light of the related documents, the conclusions about the education practices during the Ottoman Empire reached.

5. A comparison was made between the last period of the Ottoman Empire and today.

\section{Findings}

\subsection{Findings about the Last Period of the Ottoman Empire}

This study covers three documents dated 23rd August 1895, 15 March 1906, and 2nd February 1911. According to the documents, it can be understood that inspectors had important roles within the education system of Ottoman State. Beside, their roles were clarified in detail as well. It can also be seen that governmental department responsible from primary schools had published instructions for inspectors consonant with the instructions of ministry of education describing how to carry out their duties. For community schools of people amongst the minorities, who converted to Islam, their need for inspectors were emphasised. For the inspection of those schools, one head inspector and one vice inspector (with an origin of population department) were appointed. Gender based (girls only or boys only) schools were also a part of their inspection.

Instructions for inspectors were as follows: Duty boroughs of each inspector should be divided into two sections. Though official education language was Turkish, especially in Arabic speaking regions, Arabic speaker inspectors were still needed. So where needed, inspectors were allowed to take assistance of experts with Arabic knowledge.

Ottoman alphabet, ilmihal (information about daily religious activities), dini akait (religious belief knowledge), tecvit (recitation types for Quran), and writing font should be sülüs or rika (some types of Arabic writing). In addition to these requirements, cleanliness of students and hygiene should be inspected. Five times daily prayers should be carried out with teachers. School attendances should be checked and unattended and their families should be fined in cash and local governors should be informed about those students' situation. Inspectors should report inefficient and unsuccessful teachers beside the local governors, who decide unnecessary holidays. Local governors should be informed about school leavers by the inspectors. Final decision about school leavers should be decided by local education commission. They are also responsible for reporting disciplinary cases about both teachers and students to town governors if appropriate action is not taken, then to the province governors. Prayer rooms and mosques that need amendment and restoration in schools should be reported to town governors. Inspectors are responsible to inspect not only parish primary and secondary schools but also converted (to Islam) people's 
schools; they should advice teachers to give attendance tables and forms of students monthly to local education governors.

Inspection regions, divided into two, should be inspected interchangeably in every six months by head inspector and vice inspector. When needed, both inspectors can work on one region at the same time having to become responsible to take an information document from teachers of schools inspected to give local education governors. Inspectors should be careful about obeying the rules written in this instruction document and general rules of inspection on condition that they will not be paid for their travel and living expenses apart from their ongoing salary payments that are calculated beforehand regarding these costs. This instruction has been confirmed by education commission and approved by prefecturate (Commission, members: accountant, vice president and president).

Moreover, while implementing inspections:

1. Appointed inspectors are not allowed to inspect same region or schools more than once in limited period of time. If an inspector does not visit the region or school $\mathrm{s} / \mathrm{he}$ is responsible for a couple of times in a week, $\mathrm{s} / \mathrm{he}$ will be accepted as resigned or sacked depending on the situation.

2. Schools should be three levels: First and secondary levels should form primary schools and third levels should form secondary schools. Types of courses taught at these schools should be approved by prefecturate in regard with the national curriculum.

3. First level primary school teachers' recruitments should be done by parish governors while teachers of second and third levels are recruited either by governors at the capital city or province governors without any salary change. Newly recruited teachers, too are responsible for students' hygiene habits (toilet usage and tidiness of dresses), frequency of obeying the rules, degree of implementing 5 times prayers properly. Additionally, inspectors have the authority on behalf of parish governors to change schools of irregular attendant, unsuccessful, and inefficient communicator (with local people) teachers that they work at.

4. Teachers are responsible for preparation of two copies of attendance forms monthly to be signed by inspectors. Those copies should also be seen by local education commission and sent to city governorship. Inspectors should participate in graduation exams at schools, approve diplomas with education commission members, and record the number of students acquired diploma.

5. This document should be printed in required amounts and sent to related bodies. (23 August 1895, main file no: 20, File no: 284).

According to another document, province education governors ask for attendance reports for teachers and porters of village schools. They expect inspectors to audit whether curriculum is followed properly or not. Student attendance forms are an issue in this second document as well. Suggestions and refinements mentioned by inspectors should be put into action. This newer document acknowledges that travel and living expenses of inspectors will be paid to them later on. However, when this document is taken into account, it can be understood that school inspections were not carried out regularly as ordered (15 March 1906, main file no: 61, File no: 918).

A later dated document reveals that inspectors were confused by whether or not to audit secondary schools. Doubts of inspectors were answered in the same document as to inspect secondary schools with local education ministers but not high schools. (2 February 1911, main file no: 62 , File no: 1167 ).

\subsection{Education Inspection in Modern Turkey}

There are 2 legal texts to be considered in this issue. The first is the Decree on the Organization and Duties of the Ministry of National Education. This decree was published in 2011, updated in 2016. The second is the Ministry of National Education's inspection board regulation issued in 2017.

The organizational structure of the Ministry has been rearranged by the Decree Law No. 652 on the Organization and Duties of the Ministry of National Education published on 14 September 2011. According to this arrangement, the Board of Inspection Board was abolished and instead, the Directorate of Guidance and Audit was established. The duties of the Directorate of Guidance and Supervision are: The Board of Inspectors serves on behalf of the Minister with the order or approval of the Minister. Ministry's personnel, ministry's schools and institutions, private education institutions and persons are in the field of duty of the Ministry. It makes plans and programs for the subjects that fall under the Ministry's mandate and guides them. Control and supervise the services made by the Ministry in cooperation with the relevant persons and institutions. Analyze the processes and results of works according to legislation, predetermined goals and targets, performance criteria and quality standards. It compares and measures these results. It evaluates based on evidence and reports the results obtained. They pass these reports to the relevant units and people. Inspection and investigation work and transactions within the scope of the Ministry's duties and authorities shall be made through the Ministry of Education Inspectors with an understanding of the Ministry's organization and staff and the activities and transactions of all kinds of institutions under the Ministry's supervision with a precautionary approach to prevent irregularities, Guidance, on-the-job training, supervision, evaluation, investigation and research services of the educational and non-formal education institutions and national education directorates at every level are carried out through the Ministry of Education Inspectors. All 
audited entities and persons, even if secret, must give all the documents, books and information to the inspectors. Ministry of Education Inspectors are authorized to request information, documents and records. The Board of Inspectors, the Ministry of Education Inspectors and the Assistant Ministry of Education Inspectors. Ankara is the task center of the Presidency. This center is also the study center of the inspectors assigned to the Presidency units [14].

In accordance with the Internal Service Directive of the Ministry of National Education, Guidance and Supervision, the Ministry of Education inspectors carry out the necessary procedures in the fields of education, training and management in order to improve the quality of education and to contribute to the education system [14].

According to the Regulation on the Inspection Board dated August 20, 2017, the Duties, Authorities and Responsibilities of the Inspectors and vice inspectors are as follows (Clause 34): The Ministry of Education inspectors are obliged to complete the reports to be issued within twenty days after the inspection, guidance, examination and investigation. Inspectors should contribute to the professional development of assistant inspectors they work with. They carry out the work in the units, committees and commissions to be assigned. They initiate necessary legal procedures for the corruption they have learned during the audit and are outside the mandate. They will immediately report the corruption to the Chairman of the Inspection Board. They collect evidence about corruption. Problems observed during the implementation of the legislation are reported. Vice of inspectors can not independently audit, investigate, investigate and preliminary investigate. These tasks can be carried out by the inspectors who are working with them [14].

According to the Ministry of National Education's inspection board regulation issued in 2017, inspectors identify the results of their audit, guidance, research, evaluation, review and preliminary review work with the following report types (Clause 53):

a) Audit report.

b) Guidance report.

c) Monitoring and evaluation report.

d) Research report.

e) Report of the crime proclamation.

f) Review report.

g) Investigation report.

h) Preliminary examination report.

\section{Conclusions and Discussion}

The basic education institution in the Ottomans is the madrasa. In the Ottoman era, madrasas, education and scientific institutions are established and developed in accordance with the state philosophy and organize education and training accordingly. In addition, the class is also a basic non-formal education institution [4].
When the above documents are examined as a whole, it is understood that in the period of Ottoman Empire, education is also provided by using Arabic other than Turkish. Also inspection is regular, education is more religious, and cleaning (hygiene) practices are very important.

It is also understood that educational inspectors are in financial sanctions against families who have conducted a follow-up activity for students who have not attended school and have not sent their child to the school. This situation is similar to the present day to a great extent. As a matter of fact, "Governors, primary school inspectors and municipal police officers are obliged to assist the parents or guardians or heads of families and school administrations by providing attendance to compulsory primary education institutions of primary school children and to take all kinds of precautions. The students who do not attend will be searched in by school administrations and primary school inspectors for reasons of absenteeism and efforts will be made to eliminate the material and moral causes that prevent them. If these reasons cannot be remedied, the situation shall be reported to the governor of the villages, and to the district governors and governors in other places. The necessary measures are taken by these authorities. These duties of school administrators and governors continue at every stage of the inquiry about the absent students." [5]

It is the duty of the inspectors to make the necessary attempts to repair the old school buildings to be repaired and to ensure the continuity of the students to the school.

The inspectors have different statuses among themselves as chief inspector and assistant inspector. Inspectors have to do the inspection according to certain standards, not random. Inspectors will pay attention to the fact that the courses set by the Ministry of Education are not taught during the course of the inspection. Inspectors will check whether the newly appointed teachers look at the cleanliness of the students and the cleanliness of the toilet. In addition, students will continue to read and pray regularly. Teachers who cannot cooperate with the public and do not attend regularly will be replaced. The inspectors will be present at the examinations to be held in the schools and will approve student diplomas. If three documents are evaluated together, secularism looks like affected inspections earlier than the declaration of Turkish Republic as religious education seems to be omitted from inspectional interests in later instructional documents. When Ottoman period is compared to contemporary Turkey, it can be understood that there is a common issue of inspecting the attendances of teachers, students, and porters in both era.

The last period of the Ottoman Empire was ruled from Istanbul and education policies were determined here. Education policies were central because they were managed by Istanbul. Modern Turkey is managed in Ankara and again has a central feature. The area of the Ottoman Empire was 4,980,000 $\mathrm{km}^{2}$ in 1913. Modern 
Turkey is 814,578 square kilometers. Plot differences due to the domination of the Ottoman Empire established in a region where there are many different cultures, whereas Turkey is said to be more homogeneous. This leads to the conclusion that the adoption of different educational policies in different regions is necessary for the Ottoman Empire.

Educational inspections in the Ottoman Empire have taken cultural diversity to a large extent. However, it is largely Islamic center. On the contrary, it can be said that the education inspection of the Republican period regarded all the components of the society as culturally similar. With the legal amendment made in 1924 and 1937 [1], secularization in the state administration was adopted. For this reason, it can be said that the education policies of the Republican era were in the framework of secularization.

In the Ottoman Empire, the education inspectors made assessments (worship, cleaning, etc.) on the daily lives of the students. However, the evaluation criteria in Turkey today are completely changed. Assessment is based on exam success.

In the Ottoman period, the educational inspections were largely focused on education, learning and curriculum; but nowadays it can be said that the duties of the inspectors are mostly control of bureaucracy, fight against corruption and guidance. Indeed, inspection of teachers and students in Turkey with legal amendments in 2016 and 2017, the application has been removed. In other words, there is no teaching or course supervision made by education inspectors in Turkey.

There is no clear regulation regarding the appointment of education inspectors during the Ottoman Empire period; it is seen that the inspectors were selected among civil servants, clerics and various professional groups [15]. According to the Inspection Board Regulation issued by the Ministry of National Education published in 2017, the Inspection Board is composed of the Chairman and the heads of departments, and the inspectors and vice inspectors. The chairman depends on the Minister (Clause 4). In order to be appointed as an education inspector, it is necessary not to be thirty-five years old. The candidates who will take the exam for the inspectorate consist of two groups: the first is the inspector candidates who are not teachers. These are graduates of law, political knowledge, economics and administrative sciences, economic and business faculties, or equivalent higher education institutions. The second one is the inspector candidates of teacher origin. They must have been teaching for at least 8 years (Clause16). Inspector candidates are first taken to a written examination of their field. Those who pass this exam will be taken to the oral exam. Those who succeed in this exam are appointed as vice inspectors. The assistant inspector lasts three years. At the end of this training, prospective inspectors are taken to a qualification examination. Those who succeed in the exam are appointed as inspectors. Employees who work as inspectors for at least 8 years may be appointed chief inspector. They have to enter a new test to be appointed chief inspector (Clause 31). The inspectors who succeed in this exam become chief inspector.

When we look at the applications in the world, it seems that the most striking example is in England. The institution named in Ofsted in England is composed of education inspectors. Ofsted is an institution that inspects training on behalf of Her Majesty. The tasks of Ofsted can be briefly summarized as follows: inspecting maintained schools and academies, some independent schools, and many other educational institutions and programmes outside of higher education; inspecting childcare, adoption and fostering agencies and initial teacher training; publishing reports of our findings so they can be used to improve the overall quality of education and training; regulating a range of early years and children's social care services, making sure they're suitable for children and potentially vulnerable young people; reporting to policymakers on the effectiveness of these services. Ofsted have around 1,500 employees across their 8 regions: East Midlands, East of England, North East, Yorkshire and Humber, North West, South East, South West, West Midlands, London. Ofsted, also directly contract with more than 1,500 Ofsted Inspectors to carry out inspections of schools and further education and skills provision [16]. It can be said that Ofsted's inspection practices are similar to the period of the Ottoman Empire because of being directly related to education. In contrast, today's inspection practice in Turkey is based in more than Ankara. And it is very bureaucratic rather than directly related to educational inspection. It does not focus on the development of the education process.

When the above information is evaluated as a whole, it can be said that the education control in the Ottoman state is oriented towards human training and education; In today's Turkey has more to do with recent government regulations that faces the bureaucratic structure; it can be considered that there are different applications in this regard in the world. 


\title{
APPENDIX 1
}

\author{
(Ottoman Language Version)
}

Document 1

\section{Tarih: 04/R /1313 (Hicrî) Dosya No:284 Gömlek No:20 Fon Kodu: MF.MKT. \\ L azkrye dahilinde bulunan mektep lerin teftiși için tayin edilen müfettișlerin vazifeleri ve harcırahları hakkmda vilayete bilgi verild iği}

1. Belge: Lazkiye Sancağı tarafından gönderilen talimatların incelendiği ve bunların maarif talimatı ile aynı hükümleri taşıdığı, bundan dolayı bu talimatın uygulanması ve tayin olunan müfettişlerin maaşlarına ek olarak herhangi bir ödeme yapılmaması hususunda Beyrut vilayeti'ne hitaben Maarif Nezareti'nden yazılacak olan yazının müsveddesi.

Tarih: 4 R.ahir 1313 -11 Ağustos 1311 (23 Ağustos 1895)

2. Belge: Lazkiye Sancağı'nda buluna bazı mekteplerin teftiși ile ilgili olarak tayin olunan müfettişlerin vazifelerine dair Lazkiye Maarif İdaresi'nce kaleme alınarak, Lazkiye Mutasarrıflığından Beyrut Vilayeti'ne gönderilen talimat ile bu hususta Beyrut Vilayeti Maarif Müdürlüğü'nden tanzim olunan diğer talimat tetkik olunmuștur. Bölgenin durumuna göre bu talimatlardan birinin veya Maarif Nezareti tarafindan uygun görülecek yeni bir talimatın uygulanmasının Maarif Nezareti'nce bildirilmesi amacıyla bu talimatların gönderildiği hususunda Beyrut Valisi Abdi imzasiyla Maarif Nezareti'ne gönderilen tahrirat.

Tarih: 9 Muharrem 1313 -19 Haziran 1311 (1 Temmuz 1895)

3. Belge: Lazkiye Sancağı tarafından gönderilen talimatların incelendiği ve bunların maarif talimatı ile aynı hükümleri taşıdığı, bundan dolayı bu talimatın uygulanması ve tayin olunan müfettişlerin maaşlarına ek olarak herhangi bir ödeme yapılmaması hususunda Maarif Nezareti Mekatib-i İbtidaiyye Müdürlüğü mührüyle mühürlü olan olan 29 Temmuz 1311 tarihli yazı ile bunun altında yine aynı husus ile ilgili olarak aynı kararın yer aldığg Meclis-i Kebir-i Maarif mührüyle mühürlü olan olan yaz1

Tarih: 11 R.evvel 1313 - 21 Ağustos 1311 (2 Eylül 1895)

4. Belge: (Belgenin birebir transkribi yapılmıştır)

“ (1. Sayfa ) Bâ-irade-i seniyye Lazkiye Sancağı dâhilinde tâ'ife-i hidâ'iyye (İhtida edenler-Nusayriler için olmalı) içün inşâ ve ihyâ buyurılan kırk bâb mekâtib-i ibtidâ iyye ile müceddeden tertîb ve küşâdı iktizâ iden Cebele ve Merkab ve Sayhun Kazâları mekâtib-i rüşdiyyelerine ve 'inde'l-îcâb livâ dâhilinde mine'l-kadîm mevcûd bulunan zükûr ve inâs mekâtib-i sibyâniyyenin teftîş-i ahvâl ve tedrîsi ve tahsîlât-1 müktesibelerine derece-i fevka'l-'ade nazar ve dikkat ve teftîşât-1 mütemâdiyye icrâsıyla husûsât-1 sâ 'irenin bi-hakkın hüsn-i îfâsına birisi müfettiş-i evvel ve diğeri müfettiş-i sâni olmak üzere vilâyet-i celîlenin fî 4 Nisan sene 1310 târîh ve üç yüz otuz üç nomerolu emr-nâme-i 'aliyyesinde irâde buyurulduğu üzere müfettiş-i evvelliğe reşâdetlü Şeyh Saib Efendi ve sânîliğine sâbık nüfûs me'mûru Necib Efendi ta'yîn buyurulmuş olduklarından mûmâ-ileyhümânın îfâ ve icrâ idecekleri mu'âmelât-1 teftîşiyyeye dâ'ir kaleme alınan ber-vech-i zîr ta'lîmâtdır

Birinci Mâdde Lazkiye Sancağı nefs-i merkez kasaba ile mülhakâtı bulunan Cebele ve Merkab ve Sayhun Kazâlarıdır ki dört kazâdan 'ibâretdir işbu kazâlar ikiye taksîm ile her iki kazâ işbu ta 'lîmâtın on birinci mâddesi mûcebince bir müfettiş tarafindan münâvebeten teftîş idilecekdir.

İkinci Mâdde Lazkiye livâsı dâhilinde bulunan ahâlî kâmilen evlâd-1 'Arab olmak mülâbesesiyle bunların evlâd ve etfâline ta'lîm ve tedrîs idilmek üzere evvelce vilâyet-i celîlece tab' itdirilüb mekâtib-i mevcûdeye tevzî' idilan kütüb ve resâ'ilin cümlesi 'Arabiyyü'l-'ibâre ve usûl-1 kadîmeden oldığından ol vecihle ta 'lîm ve tedrîs idilmekde olub binâ'en-'aleyh devletin lisân-1 resmîsi Türkce ise de burada Türkce lisâna âşinâ mu'allim olmadığından kırâ'at idilecek kütüb ve 'ulûm-1 dîniyye ve sâ'ire usûl-1 cedîde üzere şâkirdâna ta 'lîm itdirilmesine ictihâd (gayret) itdirilecekdir.

Üçüncü Mâdde Evvelâ mekteblerde usûl-1 cedîde üzere kırâ’at olunacak Elifbâ-yı Osmanî ve 'ilm-i hâl ve 'akâ'id-i dîniyye ve tecvîd üzere Kur'ân-1 Kerîm ve sülüs ve rik'a hatlarıyla 'ilm-i hesâbdan i'mâl-i erba'a ya'nî cem'-i tarh darb-1 taksîm usûllerinin bi-sehmihu hâl (eşit bir şekilde) ta 'lîm itdirilmesine gayret ve ictihâd itdirilecekdir.

Dördüncü Mâdde Mekâtib-i mevcûdede bulunan şâkirdânın nezâfet (temizlik) ve tahâret ve beş vakt namâzlarını mekâtib-i mezkûre ile inşâ buyurulan mesâcid-i şerîfelerde mu'allimleriyle berâber edâ ve îfâsına begâyet dikkat ve i'tinâ ideceklerdir.

Beşinci Mâdde Bilâ-'özr-i şer‘î mektebi terk iden şâkirdân ve terk itdiran ebeveynlerine ma'ârifin ol bâbdaki fî 3 Mayıs sene 209 târîhli karâr ve meclis-i idâre-i livânın tasdîki tahtında ta 'mîm idilan tahrîrâta tevfîken haklarında lâzım gelan cezâ-yı nakdî usûlü icrâ idilmek üzere keyfiyeti bâ-jurnal makâm-1 mutasarrıfîye 'arz 
ideceklerdir.

Altıncı Mâdde Mekâtib-i ibtidâ'iyye ve rüşdiyye mu'allimlerinden her kîm olursa olsun işe yaramayan ve bilâ-ruhsat ve bilâ-mûcib mektebi terk ve ta"tîl iden kesânın esâmîleri kezalik bâ-jurnal müfettişler tarafından huzûr-1 sâmî-i mutasarrıfîye 'arz idilüb haklarında lâzım gelan mu'âmele ma'ârif komisyonunca icrâ idilecekdir.

Yedinci Mâdde Müfettiş-i mûmâ-ileyhümânın kendi dâ 'ireleri dâhilinde ve mekâtib derûnunda gerek hocaların ve gerek şâkirdânın usûl ve adâb-1 'umûmiyyeye bi'l-cümle nisâf (?) idecekleri mu'âmelât ve meşhûdâtlarını evvelâ kang1 kazâ dâhilinde o kazâ kâ'im-makâmına oradan bir fầide görilemez ise livâ mutasarrıflığına 'arz ve ifâdeye mükellef olacaklardır.

Sekizinci Mâdde Gerek mekâtib-i mevcûdeden ve gerek bunlar ile bir sakf ve çatı altında bulunan müberrât-1 seniyyeden olan mesâcid-i şerîfenin muhtâc-1 ta 'mîr ve taslîh olanları var ise keyfiyetin bâ-jurnal kangı kazâ dâhilinde ise o kazâ hükûmetine ifâdesine müsâre'et eyleyeceklerdir.

(3. Sayfa) Dokuzuncu Mâdde Her kazâ dâhilinde onar bâbdan kırk bâb tâ'ife-i hidâ'iyye mekâtibi olmak üzere inşâsı irâde buyurılan mekâtib-i mevcûdeden mâ'adâ birisi Cebele ve dîğer ikisi Sayhun Kazâsı ki cem'an üç bâb mekteb hünüz inşâ idilmamiş ise bunlar dahî 'uhde karîbde hitâm bulacaklarından cümlesinin ve bunlardan başka mekâtib-i mevcûde-i sıbyâniyyenin ve derdest-i küşâd bulunan mekâtib-i rüșdiyyenin her bir husûsât-1 teftîșeleri müfettiş-i mûmâ-ileyhümâya mevdû‘ dur.

Onuncu Mâdde Müfettiş-i mûmâ-ileyhümânın dâ'imî sûretle geşt ve güzâr idecekleri mekâtibin bi'l-cümle ta'lîm ve tedrîsleriyle berâber mevcûd bulunan şâkirdânın mâh be-mâh 'aded ve devâm cedvellerinin tanzîm ve isrâ's1 (uygulanması) nazar-1 i'tinâya aldırılarak beher ay gâyesinde (sonunda) merkez ma'ârif şu'besine yetişdirilmesini mu'allimlerine emr ve tenbîh ideceklerdir.

Onbirinci Mâdde Dört kazâ dâhilinde olub ikiye mukassem olan mekâtib-i mevcûdenin birinci altı aylı̆g 1 müfettiş-i evvel devr ve teftîş ideceği gibi ikinci altı aylığg dahî müfettişsi sânî devr ve teftîş itmek ya'nî Cebele ile Merkab Kazâları dâhilindeki mekâtib-i ibtidâ' îye altı ay kadar müfettiş-i sânî devr ve teftiş ider ise altı ay sonra müfettiş-i evvel devr ve teftîş itmek ve müfettiş-i evvelin devr ve teftîş ideceği Lazkiye ile Sayhun Kazâları dâhilindeki mekâtib-i ibtidâ’iyyeyi müfettiş-i sânî devr ve teftiş idecekleri hâlde mu'âmelât-1 teftîşiyyeye bi-hakkın 'atf-1 nazar-1 dikkat idilmiş ve devr dâ'im olmuş dimek olacağından ol vecihle hareket ideceklerdir ve 'inde'l-îcâb her ikisi berâber bulunacakdır.

Onikinci Mâdde Müfettişleri devr idecekleri mekâtib kang1 kazâ ve karye dâhilinde ise ol karyenin mekteb mu'alliminden bir kit'a şahâdet-nâme ahz ile ma'ârif komisyonuna i'tâ ideceklerdir.

Onüçüncü Mâdde İşbu ta'lîmât ve mektebler hakkında ma'ârifin kadîm program ve kavâ'id-i mevcûdesi mûcebince îfâ-yı mu'âmeleye sa'y ve gayret ideceklerdir.

Ondördüncü Mâdde Müfettiş-i mûmâ-ileyhümâ esâsen harc-1 râhsız olarak yalnız ma'âş̧la îfâ-yı vaziffe içün ta'yîn olunmuş olduklarından işbu ta'lîmât mûcebince geşt ve güzâr ve îfâ-yı vazife-i mükellefelerinden dolayı bir gûnâ harc-1 râh talebine hakk ve selâhiyeti olamıyacakdır

Onbeşinci Mâdde İşbu ta'lîmâtın meclis-i idâre-i livâca dahî yegân yegân tedkîk ve kırâ’atıyla ıslâh ve tebdîli iktizâ eyler bir elfâz ve ta'bîrâtı var ise icrâ-yı îcâbıyla li-ecli't-tasdîk vilâyete takdîmine karâr virildi fî 20 Mart sene 1311

A'zâ Kasım en-nevvâk

A'zâ Harun

A'zâ Muhâsebeci es-Seyyid Mehmed Fazıl

Ed-dâ'î Re`îs-i Sânî Mehmed Saib

Ed-dâ‘î Lazkiye Ma'ârif Komisyonu Re î̀si Nâ'ib

es-Seyyid Mehmed Nureddin

\section{Meclis-i İdâreden fî 24 Mart sene 311}

Mekâtib müfettişlerinin vazîfelerine dâ'ir livâ ma'ârif şu'besinden tanzîm ve i'tâ kilınan işbu ta 'lîmât meclisce dahî bi'l-mütûla'a mündericâtı muvâfık-1 hâl ve maslahat olmağla lefiyle vilâyet-i celîleye 'arz ve istizân-1 keyfiyete karâr virildi fî 1 Nisan sene 311

\section{Meclis-i idâre-i livâ-yı Lazkiye}

(2. Sayfa ) Birinci Mâdde Cebele Merkab ile merkez ve Sayhun Kazâları devr ve tebdîl sûretiyle müfettiş-i evvel ve sânînin altışar ay müddetle mütevâliyen (aralıksız olarak) devr-i teftîşde bulunacağından ve anların harc-1 râhı ma'âşları meyânına idhâl kılındığından mekâtib-i mevcûdenin nîk ve bed ahvâline müştereken ve doğrıdan doğriya müfettişler kat'iyyen mes'ûl ve haftada birkaç def'a devr ve teftîş vazîfesini îfâ itmiyan müfettiş müsta'fî ve ma'zûldür.

İkinci Mâdde Mekâtib üç mertebeye ayrılarak birinci ve ikinci derece ibtidâ'î ve üçüncü rüşdiyye ittihâz kılınmağla ber-vech-i müfredât her birinin ders cedvelleri ma‘ârif-i 'umûmiyye nizâm-nâmesine tatbîken meclis-i idâre-i vilâyetce bi't-tasdîk işbu ta'lîmâta rabt idilmişdir.

Üçüncü Mâdde Birinci derece mekteblerinin mahallince ve ikinci derece ve rüşdî mu'allimlerinin vilâyet ve Der-sa'âdetce intihâb ve ta'yîni mukarrer olmağla tahsîsât-1 hâzıra dâ ir ma 'âşât tezyîd ve tenkîs idilememek şartıyla meclis-i idâre-i vilâyetce ber-vech-i âtî ta 'yîn ve tahdîd olunmuşdur ve talebenin nezâfet ve tahâretinden ve emr-i tahsîlce sa'y ve ikdâmdan ve 'ann-cemâ'atin farîze-i salâtı îfâ itmiyanler dolayı mu'allimler mu'âteb ve mes'ûl tutulmuş ve devâmsızlığ ve ahâlî ile imtizâcsızlığ ve'l-hâsıl 'adem-i muvaffakiyet görilan mu'allimler derhâl tebdîl idilmesi ilcâât-1 mahalliye nâmına usûl-1 ittihâz kılınmışdır.

Dördüncü Mâdde Mu'allimler talebenin devâm cedvelini ikişer nüsha olarak bi’t-tertîb muttariden (sıralı ve düzenli olarak) her ay nihâyetinde müfettişlere tasdîk itdirüb mahallî ma'ârif komisyonuna îsâl ve oradan bir nüshası ba'de'l-kayd ve tasdîk vilâyet-i celîleye gönderilecekdir beher mekteb imtihânında müfettişler 
hâzır bulunmağa mecbûr olub virilecek nomerolarda mümeyyizlerin sıfatını takınarak şahâdet-nâmelerin birinci derecede anlar (onlar) ve ba'dehu Lazkiye Ma'ârif Komisyonu tarafindan tasdîk idilüb ashâbına virilecek ve hey'et-i 'umûmiyyesini nâtık bir cedvel yapılub bir senede kaç talebeye şahâdet-nâme virildiği anlaşılmak ve tescîl olunmak üzere vilâyet ma ârif idâresine irsâl olunacakdır.

Beşinci Mâdde İşbu ta'lîmâtdan mikdâr-1 kâfî vilâyet matba'asında tab" idilmekle beher mektebde bir levha ile dershâneye ta 'lîk ve müfettişler ile Cebele Merkab Sayhun ma'ârif meclisleri ve kâ`im-makâmlara tevzî‘ idilerek me' mûrîn-i mülkiyye kendi idârelerindeki mekâtib üzerine mu'allim ve müfettişlerce olan vezâ'ifin hakkıyla cereyân idüb itmediğine muttali` olarak tâ’ ife-i hidâye içün cânib-i akdes-i hilâfet-penâhîden ihtiyâr buyurllan bu nice 'âtıfetden dolayı devletce semere-i nâfi'a iktitâfina fi' ilen ve mâddeten dâmen-i dermiyân olarak meşhûdât ve mütâla'ât-1 vâkı'alarını mutasarrıfîne ve lede'l-hâce vilâyet-i celîleye 'arz itmeğe Merkab ve Sayhun ve Cebele kâ`im-makâmları me’mûr ve mükellef ve mecbûrdur"

Document 2

Tarih: 25/M /1324 (Hicri) Dosya No:918 Gömlek No:61 Fon Kodu: MF.MKT. İșkodra'd a bulunan ibtid ai ve rüșdiyeler birkaç sened ir teftiṣ ed ilemediğind en Draç Sancağı da dahil-i teftișat için memurlar gönderilmesi ve harcurahlarmm tesviyesi.

1. Belge: İşkodra Vilayeti dahilindeki rüşdiyye ve ibtidai mektepleri 7-8 seneden beri teftiş edilmediğinden, bu mekteplerle birlikte Draç Sancağ dahilinde bulunan bütün ibtidai mekteplerinin birer birer köy köy teftiş edilerek muallimleriyle hademesinin işlerine devam edip etmedikleri, program gereğince tedrisatta bulunup bulunmadıkları, ahali tarafindan talebelerin vakt ve zamanıyla mekteplere gönderilip gönderilmediklerinin teftişi için uygun memurlar gönderilerek dönüşlerinde izlenimlerini kaydedecekleri raporlar gereğince yapılması gerekenlerin icra edilmesi gerektiği, bunlara ilave olarak bu memurlara Grekli harcırahların verilmesi isteği ile İşkodra Vilayeti Maarif Müdürü mührüyle Maarif Nezareti'ne gönderilen tahrirat.

Tarih: 25 Zilhicce 1323 -6 Şubat 1321 (19 Şubat 1906)

2. Belge: İşkodra Vilayeti'ndeki okulların teftişi isteğine karşılık, bu okulların miktarı ile merkeze uzaklıkları ve ne kadar yolluk verilmesi gerektiği hususunda gerekli araştırmanın yapılarak gönderilmesi için yazı yazılması hususunda Meclis-i Kebir-i Maarif mühürlü tahrirat.

Tarih: 2 Mart 1322 (15 Mart 1906)

Document 3

Tarih: 03/Ra/1329 (Hicrî)

Dosya No:1167

Gömlek No:62

Fon Kodu: MF.MKT.

Maarif müfettişlerinin mekatib-i idadiyeleri de teftişi konusunda yaşanan ihtilaf.

1. Belge: (Belgenin birebir transkribi yapılmıştır)

'Cezair-i Bahr-1 Sefid Vilayeti Maarif Müfettişliği' antetli kağıda yazılmıştır

"Huzûr-1 'âlî-i cenâb-1 vilâyet-penâhîye

Sa'âdetlü efendim hazretleri

Ma'ârif Nezâret-i celîlesinden ahîren vârid olan vilâyet ma'ârif müdîrleriyle ma'ârif müfettișlerinin vezâ'ifine müte'allik ta'lîmât-nâmede müfettişlerin tedrîsât-1 tâliye-i (ibtidaiden sonra ve aliden önce gelen mektep eğitimi) resmiyye ve husûsiyye hakkında dahî rapor tanzîm eylemeleri muharrer olmasına binâ'en 'ale'l-usûl o bâbdaki meşhûdât ve teftîşât mı rapor şeklinde 'arz eylemek üzere mekteb-i i'dâdîye mürâca'at eylemiş isem de mekteb-i mezkûr müdîriyetince merci'inden hakk-1 teftîşimi âmir bir teblî̆g olmadığı cihetle 'âcizlerini kabûlde ma'zûr bulunduğumu ifâde eylemiş ve ta'lîmât-nâme-i mezkûr her ne kadar müdîr-i mûmâ-ileyhe irâ'e olunarak teftîşe olan selâhiyetim tasdîk idilmiş ise de sâlefü'l-'arz merci'nin emr ve teblîği olmadığı te yîden beyân itmiş oldığından vazîfe-i 'âcizânemin te'ehhür-i icrâsı yüzünden bi'l-ahere dûçâr-1 mes'ûliyyet olmamak üzere mekteb-i mezkûr idâresine teblîgât-1 mukteziyyede bulunmasının ma'ârif müdîriyetine irâde buyurulmuş ve mekâtib-i i'dâdiyyeye olan hakk-1 teftîş-i bendegânem ma'lûm olmak üzere keyfiyetin Sakız ve Midillü Mutasarrıflıklarına dahî emr ve teblîğ buyurulması mütesâmihdir (?)ol bâbda mer ve irâde efendim hazretlerinindir

Fî 18 Kânûn-1 sânî sene 1326 (31 Ocak 1911)

Mühür: Vilâyet Ma'ârif Müfettişi Panayot"

2. Belge: (Belgenin birebir transkribi yapılmıştır)

"Nizâm-nâme-i mahsûsda vilâyet ma‘ârif müfettişlerine mekâtib-i i‘dâdiyye-i resmiyyeyi teftîş hakkı virilmemişdir 
Ta'lîmât-nâme-i mahsûsda dâhî mekâtib-i mezkûreyi teftîş idebilecekleri zikr ve tasrîh kılınmış olmayub yalnız talîmâtın bir mâddesinde vilâyet ma'ârif müdîrleri mekâtib-i i'dâdiyye müdîrlerinin ve vilâyet ma'ârif müfettişlerinin tedrîsât-1 tâliyeye müte'allik raporlarını ahz ve telakkî ider ve dîğer bir mâddesinde de vilâyet ma'ârif müfettişi tedrîsât-1 tâliye-i 'umûmiyye ve husûsiyyeye müte'allik husûsâtda ma'ârif müdîrleri ile muhâbere eyler deyü muharrer olması Panayot Efendi'nin anladığı gibi vilâyet ma'ârif müfettişlerine mekâtib-i i'dâdiyye-i resmiyyeyi teftîş hakkı bahş idemez mâddenin biri müfettişlerin tedrîsât-1 tâliyeye 'â'id raporlarını ma'ârif müdîriyetine virmelerini dîğeri de îcâbı hâlinde tedrîsât-1 tâliye-i 'umûmiyye ve husûsiyyeye müte'allik husûsâtda ma'ârif müdîrleri ile muhâbere eylemelerini âmirder. Binâ'en-'aleyh merkez vilâyet i'dâdî mektebi her sâ‘ât ve her gün taht-1 nezâret ve teftîş-i 'âcizîdedir iki ay evvel Midillü'ye 'azîmetle ora i'dâdîsi teftîş olunmuş ve meşhûdât-1 vâkı'a ve tesâdüf olunan nevâkısı nezâret-i celîle-i ma'ârife 'arz idilmişdi. Nezâret-i müşâün-ileyhâca da nevâkısın ikmâli içün îcâb iden tahsîsât bi'l-i'tâ havâle-nâmeleri makâm-1 'alî-i vilâyet-penâhîlerine peyderpey vürûd itmekdedir karîben bi'z-zât Sakız'a dahî 'azîmetle îcâb iden teftîşât icrâ kılınacağına binâ’en mârü'l-'arz iki mâddeye ve elde mevcûd nizâm-nâme ahkâmına göre vilâyet ma'ârif müfettişinin ne merkez ve ne de elviye-i mülhakadaki mekâtib-i i'dâdiyye-i resmiyyeyi teftîşe hakk ve selâhiyeti olmadığı ma'rûzdur ol bâbda

Fî 20 Kânûn-1 sânî sene 1326 (2 Şubat 1911)

Mühür: Ceâyir-i Bahr-1 Sefid Vilâyeti Ma‘ârif Müdîriyeti’”

\section{APPENDIX 2}

\section{(English Version)}

Document 1

\section{Tarih: 04/R /1313 (Hicrî) Dosya No:284 Gömlek No:20 Fon Kodu: MF.MKT. L azkrye dahilind e bulunan mektep lerin teftiși için tayin edilen müfettișlerin vazifeleri ve harcirahları hakkmda vilayete bilgi verild iği}

Document 1: It has been understood that the instructions sent by the Lazkiye district have been reviewed and that they have the same provisions as the educational instruction. Therefore, it is the draft of the letter to be written by the Ministry of Education addressing the Beirut province in the application of this instruction and in addition to the salaries of appointed inspectors.

Date: 4 R.Hahr 1313 -11 August 1311 (August 23, 1895)

Document 2: The instruction sent to the Beirut District by the Lazkiye District Office, written in the Lazkiye Education Directorate on the duties of the inspectors appointed for the inspection of some schools in the district of Lazkiye, and the other instruction issued by the Beirut District Directorate for Education have been examined. Depending on the situation of the zone, it is possible to apply a new instruction from these instructions which will be deemed appropriate by one or the education directorate. It is possible that this is the letter sent to the Directorate of Education by the signature of the Governor of Beirut Mr. Abdi.

Date: 9 Muharrem 1313 -19 June 1311 (1 July 1895)

Document 3: The Ministry of Education Directorate General of Primary Education, which has been sealed with the seal of the Directorate of Primary Education of the Ministry of Education on 29 July 1311 for the review of the instructions sent by the Lazkiye District and which has the same provisions as the education instruction and therefore no payment shall be made in addition to the salaries of the appointed inspectors the article which was sealed with the seal of the Grand Council of Education where the same decision took place in relation to the same matter under it.

Date: 11 R.Evvel 1313 - 21 August 1311 (2 September 1895)

Document 4: Fourty primary schools have been built in the town of Lazkiye for peoples who have previously belonged to other religions and were subsequently Muslim. Furthermore, in the towns of Cebele, Merkab and Sayhun (Syrian territory), it is necessary to supervise the primary schools of girls and boys, which were built beforehand. This audit will be done by two people, one of whom is an inspector other than the chief inspector. Sheikh Saib Efendi, Chief Inspector, and Necib Efendi, who had previously served as the population director, were appointed to the inspectorate as stated in the directive no. 333 published on April 4, 1310 (April 16, 1894). These inspectors will comply with the following order when inspecting:

First article: The town of Lazkaya; the center is composed of four towns, including Cebele, Mekab and Sayhun. These towns will be divided into two and audited alternately by two inspectors.

Second article: The people in the name of the mentioned regions are Arab. Although the official language of the state is Turkish, most people do not speak Turkish. Most of the teachers here do not speak Turkish either. Most of the 
course books have been prepared in Arabic fors o long. Inspectors will guide books to be read by students, religious sciences and new teaching methods.

Third article: The Ottoman Elifba (First stage book on reading and writing), which is organized according to the new teaching methods, will be taught to the students on daily basis, daily religious information (ilmihal), religion and the effective technique of reciting Qur'an (tecvid). In addition, writing will be taught in the style of Thuluth and Rika (two type of the ottoman wrtiting). Again, it will be tried to teach four transactional knowledges in mathematics.

Fourth article: The cleanliness of the students in the school will be paid attention. Students and teachers will pray together in schools and in the masjids.

Fifth article: Parents who leave the school without excuse and parents who cause their children to leave the school will be fined according to the decision dated 3 May $20 ? 9$ and the district governorship will be informed.

Sixth article: The names of teachers who do not perform their duties as well as those who leave the school without permission will be reported to the district governor by the inspectors. The education commission will also pay the necessary penalty.

Seventh article: Inspectors shall report to the district governors in the state territory in case of confrontation with teachers and student behaviors that are not common in their duties and schools.

Eighth article: If the masjids in the schools need to be repaired, this will be reported to the district governor.

Ninth article: A total of 40 classrooms shall be constructed for the new Muslims in each of the four districts, each with 10 classrooms.

Tenth article: Inspectors will be involved in the school attendance of the school, as well as the attendance of the students. The attendance schedules of the students will be filled in carefully and will be delivered to the central education directorate at the end of the month.

Eleventh article: The first two of the four towns will be supervised by one of the inspectors in the first six months. The next two schools will be inspected by another inspector. In the second half of the year, inspectors will audit themselves by changing inspection areas. In addition, two inspectors can work together if needed.

Twelfth article: Inspectors will receive a document from the village teachers about the schools to which they will transfer to each other and give it to the education commission.

Thirteenth article: In accordance with this regulation, schools will be subject to the previous education program and rules.

Fourteenth article: No travel costs will be paid to inspectors assigned to this area, because these inspectors are only paid salary.

Article fifteenth: This instruction has been published and controlled by the county administrative council. If this instruction contains an error, it shall be presented to the
Governor, provided that necessary corrections are made.

March 20, 1311 (April 1, 1895).

Member Kasim en-nevvâk

Member Harun

Member Accountant es-Sayyid Mehmed Fazıl

Second President Mehmed Saib

Lazkiye Education Commission Chairman Nâ'ib

es-Sayyid Mehmed Nureddin

From the Board of Directors,

March 24, 311 (April 1, 1895).

Lazkiye District Council

\section{Second page}

First article: Inspectors will alternately inspect the towns of Cebele, Merkab, Center and Sayhun. These two inspectors who are in charge of inspection will pay only salary, without interruption for six months, without paying the travel allowance. Inspectors who fail to perform their inspection several times a week will be deemed to have resigned or will be dismissed.

Second article: Schools will be separated into three grades. Primary schools will be first grade; secondary schools will be second grade. The curricula of these schools will be audited in accordance with the curriculum of each of them in accordance with the general education regulation. These regulations have been approved by the provincial administrative council.

Third item: The schools in the first grade will be selected from the teachers' own regions. Secondary school teachers, in the second grade, will be selected by the governor or the capital. No increase or decrease will be made to the governorships from the salaries of these teachers. Teachers will be responsible for the cleanliness of the student, will show the behaviors required for the education, the teachers will be held responsible for the behavior of the students who do not pray, the teachers who do not keep up with the people and have problems with the public will be changed immediately.

Fourth article: Teachers will sign the follow-up schedules of the students at the end of every month to the inspectors and submit them to the local education commission. An example of these charts will be sent to the governor after registration. Inspectors have to be present at examinations by schools. The inspectors are going to have their student diplomas approved after the signing of the Lazkiye education commission. The diplomas given will be registered by the Provincial Directorate of Education in order to know how many people have received a diploma in a year.

Fifth article: This regulation will be duplicated up to the need. This regulation will be sent to each school. The inspectors will cooperate with educational commissions and district governorships. Reward officers will monitor whether teachers and inspectors fulfill their duties properly. The provisions of this regulation are mandated to implement the district governorships of Merkab, Sayhun and Cebele. 
Document 2

\title{
Tarih: 25/M /1324 (Hicri) Dosya No:918 Gömlek No:61 Fon Kodu: MF.MKT.
}

\author{
İșkodr a'd a bulunan ibtid ai ve rüșdiyeler birkaç sened ir teftiş ed ilemediğind en \\ Draç Sancağı da dahil-i teftișat için memurlar gönderilmesi ve harcrrahlarmm \\ tesviyesi.
}

Document 1: The secondary and primary schools in the province of Shkodra have not been inspected since 7-8 years. All these primary schools in Draç Sanjak should be inspected one by one. It is necessary to check whether the teachers and other officials have continued their work or not and whether they are teaching according to the program. The parents will be checked by the inspectors they send and do not send their children at school. As a result of this, the inspectors will prepare reports with their impressions. According to the results of these reports, what to do should be done. It is also a document written to the Directorate of Education of the Provincial Directorate of Education in Shkodra, where such duties should be given.

Date: 25 Zilhicce 1323 - 6 February 1321 (19 February 1906).

Document 2: The letter from the Grand Council of Education states that the school should be inspected in Shkodra, and the number of these schools and the distance to the center and how much it should be paid for travel.

Date: March 2, 1322 (March 15, 1906)

Document 3

\begin{tabular}{|c|c|c|c|}
\hline Tarih: 03/Ra/1329 (Hicrî) & Dosya No:1167 & Gömlek No:62 & Fon Kodu: MF.MKT. \\
\hline \multicolumn{4}{|c|}{ Marif müfettisslerinin mekatib-i idadiyeleri de teftissi konusunda yassanan ihtilaf. } \\
\hline
\end{tabular}

Document 1: 'Cezair-i Bahr-1 Sefid Province Education Inspectorate' is written on letterhead paper

Honorable Governor

Your Majesty

Although the provincial education managers published by the Ministry of Education did not have the ability to report on official and private secondary schools after the primary school according to the provisions of the mandate of the education inspectors, there was no clear mandatory judgment in this respect. On this basis, it is not clear whether the document will be edited or the report will be edited. For this reason, I have applied for a degree and have been told by the director of this school that I am authorized to supervise the school, but since there is no clear provision in this regard, this letter has been written to the education director with the concern of creating a responsibility later. In order to clarify this issue, it is necessary to be asked to the Chiefs of Chios and Midilli. Your honor is your majesty. Fî 18 Kânûn-1 sânî year 1326 (31 January 1911)

Signet: Provincial Education Inspector Panayot"

According to the above-mentioned regulation, the provincial education inspectors are not given the authority to inspect official schools. It is not mentioned that the schools mentioned in this regulation can be inspected. It is stated that in one of these instructions, provincial education directors and provincial education inspectors can prepare reports by inspecting secondary schools. Another matter is that the secondary education inspector's secondary schools are in contact with the education directors in the sense that they are general and special. It does not mean that the provincial education inspectors, as Panayot Efendi understood by inspector mentioned here, can inspect official schools. One of the items in the ordinance requires that reports from junior high schools be handed over to the education directorate and the other orders to be in communication with the education directorate in matters concerning private and general junior high schools, if necessary. The central level of the province is under supervision at all times and every day. Two months ago, Mytilene High School was inspected and the ministry was informed to the Ministry of Education with a record. The Ministry of Education has taken all the necessary precautions to overcome these shortcomings and gradually started to transfer appropriations. It should be known that even if the schools of Chios are to be inspected, they are not authorized to inspect official high schools according to the two articles of the said regulation.

20 Kânûn-1 sânî year 1326 (2 February 1911)

Signet: Cezâyir-i Bahr-1 Sefid Province Education Directorate

\section{REFERENCES}

[1] Akyüz, Y. (2013). Türk Eğitim Tarihi. Ankara: PegemA.

[2] Aydın, M. (2014). Çă̆daş Ĕ̆itim Denetimi (6. Baskı). Ankara: PegemA. 
[3] Buluç, B. (2008). Türk Eğitim Sisteminde Teftiş ve Denetim Alt Sisteminin Gelişim Süreci. Bilgi Çağında Ĕ̈itim, 4 (27-30).

[4] Bulut, M. (1999). Osmanlı devletinde dini teşkilatlanma ve yaygın din eğitimi. http://ktp.isam.org.tr/pdfdrg/D00033/1999 c35/1999 c35 2/1999_c35_2_BULUTM.pdf Date of access: $13^{-}$Nov 2017.

[5] http://mevzuat.meb.gov.tr/html/24.html Date of access: 13 Nov 2017.

[6] Karasar, N. (1997). Bilimsel Araştırma Yöntemi (9. Bask1). Ankara: Nobel Yayın Dağıtım.

[7] Kasapçopur, A. (2007). Avrupa Birliği Ülkelerinde Eğitim Denetimi. [1] [8] http://tkb.meb.gov.tr/yayinlar/AB\%20egitim.pdf Date of access: 13 Nov 2017.

[8] http://tkb.meb.gov.tr/yayinlar/AB\%20egitim.pdf Date of access: 13 Nov 2017.

[9] Memduhoğlu, H. B. (2016). Türk Eğitim Sitemi ve Okul Yönetimi (Editörler: Kürşat Yılmaz, H. Basri Memduhoğlu). Ankara: PegemA.

[10] Öz, M. F. (2003). Türkiye Cumhuriyeti Milli Eğitim
Sisteminde Teftiş. Eskişehir: Osmangazi Üniversitesi.

[11] Sahin, S. Elçiçek, Z. ve Tösten, R. (2013). Türk Eğitim Sisteminde Teftişin Tarihsel Gelişimi ve Bu Gelişim Süreci İçerisindeki Sorunlar. The Journal of Academic Social Science Studies. 6 (5), 1105-1126. doi:http://dx.doi.org/10.9761/JASSS1336.

[12] Taymaz, H. (2010). Eğitim Sisteminde Teftiş (7. Bask1). Ankara: PegemA.

[13] Usta, M. E. ve Özmen, F. (2017). 1910/1911 Tarihli İlkokul Müfettişlerinin Görevlerine Dair Yönerge'nin Günümüz Eğitim Teftişi Uygulamaları ile Karşılaştırılması. YYÜ Eğitim Fakültesi Dergisi (YYU Journal Of Education Faculty), 2017; 14(1):1544-1573, http://efdergi.yyu.edu.tr, http://dx.doi.org/10.23891/efdyyu.2017.55

[14] http://rdb.meb.gov.tr/ Date of access: 13 Nov 2017.

[15] Özmen, F., Açıkses, E., Usta, M. E. ve Uluerler, S. (2004). Mesrutivetin İlanından, Cumhurivet Dönemine, Osmanlı Devleti'nde Eğitim Denetimi (1876-1923). Firat Üniversitesi Bilimsel Araştırmalar Birimi Koordinasyon Birini. Proje no: 1845 .

[16] https://www.gov.uk/government/organisations/ofsted Date of access: 21 Dec 2017 